\title{
Organizational Commitment as Mediating the Relationship Between Spiritual Leadership on the Sharia Hotels Performance
}

\author{
Eka Mariyanti \\ Faculty Economic and Business, \\ Dharma Andalas University, 25000 Padang Indonesia. \\ Nor Azilah Husin \\ Faculty of Business and Accountancy, \\ Universiti Selangor, 40000 Shah Alam Malaysia.
}

\begin{abstract}
The purpose of this study is to look at the role of organizational commitment as a mediator between spiritual leadership and Sharia Hotels performance in Padang City, Indonesia, with a sample size of 50 respondents, and this study uses path analysis. The results showed that spiritual leadership has a positive and significant effect on organizational commitment with a significant value of $0.000<0.05$. Organizational commitment has a positive and significant effect on Sharia Hotels Performance with a significance value of $0.000<5 \%$. Spiritual leadership also has a positive and significant effect on Sharia Hotels Performance of $0.000<5 \%$. The influence of spiritual leadership on Sharia Hotels' performance with Organizational Commitment as a mediating variable with a calculated $t$ value of $2.78>t$ table of 1.6787 .
\end{abstract}

Keywords: Halal Tourism; Sharia Hotels; Spiritual Leadership; Organizational Commitment; Sharia Hotels Performance

\section{INTRODUCTION}

Over the last few years, the relationship between Islam and tourism has been in great demand, as is the concept of Islamic tourism [1][2] and the concept of halal tourism [3]. The concept of hotels that are following sharia [4]. However, they are a lot by certain ambiguities [5]. The successful development of halal tourism must abide by Islamic teachings and principles in all aspects. Halal tourism is any object or action involved in tourism that, following Islamic teachings [6].

According to a very authoritative book entitled 'The Lawful International Union of Muslim Scholars,' the term halal is defined as "What is permissible, without restrictions, and does what is permitted by Allah SWT". According to [6], the term halal means 'permitted' according to Islamic law (sharia law), and Halal is also one of the five Islamic legal actions, al-ahkam alkhamsah, which categorizes human morals in Islam: Obligatory (Wadjib), Recommended (Mandu-b), Indifferent (Muba7i), Dislike (Makrult), and Prohibited (Flamm) [7]. From an Islamic perspective, halal refers to practices or activities that are 'allowed' following Islamic teachings, other than other elements that must be present to create "Islamic" activities or intentions, when people to do them intend to seek the pleasure of Allah SWT [6].

Word Tourism Management (2007) described halal tourism as a type of religious tourism that adheres to the teachings of Islam in the fields of behaviourism, clothing, behaviour, and diet [3]. On the other hand, Islamic tourism attracts many tourists who are interested in what is called 'Islamic culture' [7]. Islam is a universal religion. One of the main objectives of tourism in 
Islam is to introduce Islam. And also the word of Allah to all humanity. This reminder is an order from Allah SWT to Prophet Muhammad SAW in the Qur'an Saba 'verse 28 (literally) Allah SWT said: We did not send you, but as messengers to humans, give them glad tidings and warn them (against sin), but most people do not understand.

Travellers may understand Halal tourism as a market segment formed by Muslims who want to entertain and respect Muslim tourists while travelling. As a result, tourism services along the value chain must be tailored to the teachings of religion and the appropriate habits, meeting these needs. In this case, it is relevant to note how religion influences people's behaviour while travelling, but this does not mean that the motivation for travel intention comes from the religious factor. This scenario is important because, in some cases, halal tourism is not a type of religious tourism. Whether the motivation of halal tourism comes from religion or not, Muslims are expected to behave in a sharia way while travelling, regardless of travel motivation, under Islamic principles and ethics. At the same time, the researchers focus on their definitions of aspects such as halal food and drink (restaurants), halal hotels, entertainment services that respect Islamic law, even in the way of slaughtering Islamic animals. These researchers associate halal tourism with Muslim friendly tourism. However, the finding shows that the Arabs and other Muslim tourists travel for religion and culture [8].

Sharia-based hotels do not provide alcoholic drinks and only serve halal food. However, other requirements need to be noted in detail by hotels such as the operators should have separate entrances for women, separate recreational facilities such as swimming pools and fitness centres. Besides, hotels that adhere to Sharia must also pay zakat on time, and the source of financial assistance should only come from a banking system that is compliant with Sharia [9] [10]. Along with the development of sharia, hotels should follow sharia-compliant. Sharia hotels are hotels that provide services by sharia principles, which are not only limited to providing halal food and drinks, more than that, it is necessary to ensure all hotel operations operate per sharia principles.

In providing halal tourism in Indonesia, the government, through the Ministry of Tourism, has designated several regions as halal tourism destinations. The Indonesian Ministry of Tourism and Culture has developed and promoted business services in the fields of hospitality, restaurants, travel agents, and spas in ten (10) halal tourism destinations. This development is happening in several cities, namely Aceh, West Sumatra, Riau, Jakarta, West Java, Central Java, Yogyakarta, South Sulawesi, Lombok, and East Java [11]. Thus, we conclude halal tourism can attract foreign and domestic Muslims tourists. Therefore, halal tourism has good prospects and promises future foreign exchange resources [12].

Indonesia is now heading towards halal relations between Islamic countries that are considering the halal concept. Due to the growing demand for products and services is following Islamic law or Sharia law, there is an opportunity for the hotel industry to provide facilities and services that are in line with Islamic law. Sharia Hotel is a hotel that combines Islamic sharia into hotel operations. The hotel management uses a special motto, logo, interior adornment, room facilities, hotel facilities, or uniforms, or clothes worn by hotel employees.

Nowadays, Shariah Hotel business is starting to become the focus of the day because the public is offered with various hotel options to relax or hold business meetings. The hotel that pioneered the concept of Sharia Hotels in Indonesia is Sofyan Betawi Hotel, which implements Sharia management systems in its hotels. The Sofyan Hotel won the best Sharia Hotel in the world title from the Family Friendly Hotel category at the 2015 World Halal Travel Award [13]. 
This award is an annual award, a prestigious and exclusive event representing the fastest growing halal travel and tourism sector in the world.

There is no Sharia Hotel certification for West Sumatra, except at the Rangkayo Basa Hotel in Padang, because it is a part of the Sofyan Inn Hotels. The lack of certified sharia hotels is because the certification of Sharia Hotels itself has many criteria that must be met and will be issued by the National Sharia Board (DSN) under the auspices of the Indonesian Scholars Council (MUI). After issuing the certification, this hotel has validity in the application of Shariah Hotels.

The general standard of convenience for Sharia Hotels is the same as the facilities provided by conventional hotels, but based on the DSN Fatwa Regulation Number 108 / DSN-MUI / X / 2016, namely [14]:

a. Sharia hotels must not provide access to pornography and immoral acts;

b. Sharia hotels must not provide entertainment facilities that lead to polytheism, immorality, pornography, and immoral acts;

c. Food and beverages provided by sharia hotels must have obtained halal certificates from MUI;

d. Providing adequate facilities, equipment, and facilities for the implementation of a prayer room, including cleaning facilities;

e. Hotel management and employees are required to wear clothes that are following sharia;

f. Sharia hotels are required to have guidelines and/or guidelines regarding hotel service procedures to ensure the implementation of hotel services under sharia principles;

g. Sharia hotels are obliged to use the services of Islamic Financial Institutions in conducting services. Sharia Hotels in West Sumatra have implemented the above guidelines in the business operations.

For the interior decoration of sharia hotels, there should not be any living paintings in the lobby and lounge except painting on Quran calligraphy. The interior colours of the hotel are normally white, and the male and female guest rooms should be separated. The room should have a qiblat sign, a prayer mat, and Qur'an. The sharia hotel staff should wear their attire according to sharia-compliant. However, it is not only facilities that can be the basis for Shariah Hotel implementation, but also the management aspects. This specification includes recruitment, customer service, front desk, housekeeping, food, and beverage services.

The success of a hotel highly depends on employee performance. Poor performance will affect hotel success, and great performance will result in hotel success in every industry. Exploring and understanding the factors that influence organizational performance in sharia hotels is the aim of this study. Many business leaders evaluate the performance of their employees each year to help them identify areas that need to be further improved and enhanced.

Companies that benefit from other competitors through their talent can lead the market. The success of the unit needs employees' performance in different jobs under strict coordination, which means that the worker's performance is the same as the work performed. According to [15], there are two dimensions of employee behaviour in performance (task performance and contextual performance). Job performance is the behaviour of employees directly involved in the production of goods or service activities that provide indirect support to the organization's core technical processes [16]. 
Organizational commitment focuses on employee loyalty to the organization, and employees are willing to invest extra energy on behalf of the company [17]. Furthermore, [18] stated that organizational commitment is the desire of employees to stay loyal to the organization, where they work hard to meet the organizational expectations, uphold the values and goals of the organization and have a strong desire to maintain membership in the organization and willing to try to achieve organizational goals. In addition to the need for organizational commitment in implementing Sharia Hotels, other factors contribute to the implementation of Sharia Hotels, namely the Islamic work ethic and Islamic values and certainly the leadership commitment. It is crucial and challenging for the implementation of Sharia Hotels if Islamic work ethics or the applications of Islamic values are missing.

Based on the above scenario, the purpose of this study was to identify the role of organizational commitment as a mediator between spiritual leadership and Sharia Hotel performance in Padang City, Indonesia.

\section{Organizational Commitment}

\section{LITERATURE REVIEW}

The first stage of organizational commitment emerged in 1960, factors that determine the manifestations of organizational commitment have been identified [16] and their role as a mediator for almost proven organizational performance [19]. There is no doubt that organizational commitment can have major implications for the organization as a whole as well as for each individual, known as a strong predictor of employee motivation and fluctuation. The importance of organisational commitment to achieving the highest value of service quality is emphasized by theorists and also by practitioners [20] [21].

According to [22], the source of organisational commitment can vary from person to person. Employees' initial commitment to the organization is determined by their individual characteristics such as personality, attitude and their initial work experience in accordance with their expectations. Then, the organisational commitment continues to be influenced by work experience, with many of the same factors that lead to job satisfaction. It also contributes to increased organizational commitment or lack of organisational commitment: remuneration, relationships with supervisors and coworkers, working conditions, and opportunities for improvement. Over time, organisational commitment tends to be stronger because individuals develop closer relationships with their organisations and colleagues as they spend more time with them. Elderly often take advantage of the benefits they tend to develop more positive attitudes; while opportunities in the labour market can decrease with age and workers become more committed to their work [20].

\section{Spiritual Leadership}

Leadership is the art of managing others and generating their desire to achieve common goals [23] while Spiritual is a word that comes from the spirit, which is related to the spiritual qualities of love, compassion, human patience, forgiveness, satisfaction, and other things that bring happiness to oneself and others [24]. [25] postulated that Islam had made a very important contribution in many areas of human life. Concerning management and leadership, he presented several characteristics, such as how a Muslim leader must behave in a way that is appropriate for his followers to be good followers. The leader's spiritual energy plays an important role in motivating and leading his subordinates. [26]. Spirituality is one of the new fields of research [27]. Spiritual leadership plays an important role in increasing the level of organisational commitment as well as productivity. This scenario is true due to the positive impact on individuals, teams, organisational development values, and a sense of togetherness [28]. Spiritual Leadership is the use of spiritual leaders as one of the motivational behaviours 
of their subordinates in that way helps them find the moral strength that binds them to others [29].

Spiritual Leadership is a type of leadership that seeks to meet the needs and desires of employees in organisations by providing psychological needs that help them to continue working in the organisation and communicate with others, and become part of the organisation in ways that lead to efficiency in business performance [30]. To improve organisational performance through the attitude of leaders who motivate employees to achieve their organisational goals and vision [31]. [32] further emphasize that spiritual leadership is one form of leadership that can be followed by leaders in an organisation in a way that achieves its goals efficiently and effectively.

\section{Sharia Hotel Performance}

[33] argue that a company needs to consider financial and non-financial indices simultaneously when evaluating performance. Certain non-financial indices are important for the company's long-term operations, including product and employee quality.

\section{METHODOLOGY}

For this research, we employ a descriptive study to gain insight from managing Sharia Hotels, especially for employees to improve Sharia Hotel performance. In this study stated that organisational achievement was measured based on aspects of a management perspective consisting of indicators for financial or non-financial performance. This research is based on descriptive analysis because the aim is to evaluate the role of organisational commitment as a mediating variable between spiritual leadership and Sharia Hotels performance.

This study uses a questionnaire as a research instrument. We used a series of questions to obtain information about each variable related to the research objectives. The 7-point Likert Scale for these items is: 1 = Strongly Disagree, $2=$ Disagree, $3=$ Somewhat Disagree, $4=$ Neutral, 5 = Somewhat Agree, $6=$ Agree, $7=$ Strongly Agree. We developed this instrument by adopting and adapting it from previous studies. We made several amendments and modifications to fit the context of sharia hotel operations. This study used a questionnaire used by previous researchers to measure the research variables namely spiritual leadership [33], commitment [35], Steps in this achievement study were taken from [36] [37], then adapted to fit the performance of sharia hotel operations in the Indonesian context. We formulated the question of the investigation to meet the implementation of achievements in Islamic hotels. We conducted with fifty (50) respondents from the top management of sharia hotels located in Padang and analysed the statistical analysis with SPSS version 21 for the significance relationships between spiritual leadership, organisational commitment and Performance of sharia hotels. 


\section{DISCUSSION}

\section{Descriptive analysis}

Table 1. Profile of Respondents

\begin{tabular}{|l|c|}
\hline Profile & $\begin{array}{l}\text { Percentage of } \\
\text { frequency }\end{array}$ \\
\hline HOTEL CLASSIFICATION & $10.0 \%$ \\
\hline 1 Star & $16.0 \%$ \\
\hline 2 Star & $74.0 \%$ \\
\hline Unclassified & \\
\hline TRAINING RELATED TO SHARIA HOTELS & $20.0 \%$ \\
\hline Ever 1 times & $14.0 \%$ \\
\hline Ever > 3 times & $66.0 \%$ \\
\hline Never & \\
\hline LEVEL OF EDUCATION & $44.0 \%$ \\
\hline Senior High School & $12.0 \%$ \\
\hline Diploma & $42.0 \%$ \\
\hline Degree & $2.0 \%$ \\
\hline Master & \\
\hline GUEST FILTERING SYSTEMS BY & $20.0 \%$ \\
\hline Marriage certificate & $20.0 \%$ \\
\hline Identity card & $8.0 \%$ \\
\hline Ask guests directly about their marital status & $42.0 \%$ \\
\hline $\begin{array}{l}\text { Identity card, marriage certificate, and ask } \\
\text { guests directly about their marital status }\end{array}$ & \\
\hline HOTEL GUESTS COME FROM & $10.0 \%$ \\
\hline Foreign guests & $90.0 \%$ \\
\hline Local & \\
\hline GUESTS MAKE HOTEL RESERVATIONS & $62.0 \%$ \\
\hline THROUGH & $38.0 \%$ \\
\hline Offline & \\
\hline Online & $56.0 \%$ \\
\hline Certification Of Existing Sharia Hotels & \\
\hline In the process of administering DSN MUI & \\
\hline No certificate & \\
\hline & \\
\hline
\end{tabular}

Based on table 1 of the respondent profile, it is known that of the 50 respondents in the study based on the classification of sharia hotels in the city of Padang. The total of $74 \%$ of sharia hotels are non-star hotels, 2 Star hotels are $16.0 \%$, and at least 1-star hotel is 10\%. The average employee working at a sharia hotel is $44 \%$ of the level of education is a high school graduate, and many are from a vocational high school hotel and partly based on the level of education the Degree is ranked number two, $42.0 \%$ because they are top management, and the level of education will boost their careers.

For the guest filtering system that differentiates sharia and conventional hotels, it showed that $20 \%$ of sharia hotel employees check their guest documents such as checking marriage certificates and 20\% identity cards and $8 \%$ of sharia hotels ask their guests for the guests' marital status when they are unable to show their marriage certificates and Identity Card; and the average guests who stay at the Sharia hotel $90 \%$ comes from local guests and only $10 \%$ are foreign guests. The majority of the guests come to the hotel and book themselves $62 \%$ and only $38 \%$ of the respondents book online. Next, based on the results in this respondent table prove that the existing sharia hotels in the city of Padang do not yet have a sharia hotel certification from DSN - MUI (National Sharia Council - Indonesian Ulema Council) 56\% of the sharia hotels do not have certification, and $44 \%$ are in the process of administering DSN MUI.

Next, we run the reliability test by using KMO and Bartlett's test for validity test and Cronbach's Alpha for reliability test. 


\section{Assessment of Measurement Model}

Table 2. KMO and Bartlett's test (validity test) \& Cronbach's Alpha (reliability test).

\begin{tabular}{|c|c|c|c|c|c|}
\hline Variable & $\begin{array}{c}\text { Kaiser-Meyer- } \\
\text { Olkin Measure } \\
\text { of Sampling } \\
\text { Adequacy }\end{array}$ & $\begin{array}{l}\text { Bartlett's Test } \\
\text { of Sphericity } \\
\text { Approx.Chi- } \\
\text { Square }\end{array}$ & df & Sig. & $\begin{array}{l}\text { Cronbach } \\
\text { 's Alpha }\end{array}$ \\
\hline Spiritual Leadership & .767 & 674.563 & 78 & .000 & .939 \\
\hline Commitment & .853 & 545.764 & 55 & .000 & .853 \\
\hline $\begin{array}{l}\text { Sharia Hotel } \\
\text { performance }\end{array}$ & .732 & 810.788 & 66 & .000 & .933 \\
\hline
\end{tabular}

The validity test in this study uses technical factor analysis using SPSS program version 21 . The technical factor analysis used is Confirmatory Factor Analysis (CFA). The round factor analysis method used is varimax. Question items with a valid loading factor of $\geq 0.50$ indicate that the existing indicators are units of measurements that measure a common construct and can predict next expectation.

Next, we run the validity of the correlation between variables in measuring a concept by looking at the Kaiser Meyer Olkin Measure of Sampling Adequacy (KMO MSA) and Bartlett's Test of bb Sphericity significance coefficient. Coefficients of KMO MSA more than 0.50 are acceptable while coefficients less than 0.50 are not acceptable [38]. We also assess Bartlett's Test of Sphericity through a significance coefficient of less than $5 \%$ or 0.05 . The items that are declared missing are items that are grouped according to their respective variables [39] results from KMO and Bartlett's Test.

For spiritual leadership variables with 13 statement items declared valid and none of the statements below the number $5 \%$, based on the KMO results obtained a validity value of 0.767 is greater than the value of 0.50 , and all statement items are sufficient for further testing, then for variable organisational commitment, a total of 12 statement items are also declared valid because all statements are useable and no deletion of statement needed, and the last for the sharia hotel performance variable is also declared valid from the 12 statement items submitted to respondents obtained a figure of 0.732 greater than the number 0.50 . Then of the three spiritual leadership variables, organisational commitment, and sharia hotel performance are proven valid.

Reliability $>0.80$ is considered good, while $>0.70$ is considered acceptable and less than 0.60 is bad [38]. Based on the results of the reliability found, the results of the Spiritual Leadership variable 0.939, Commitment 0.853, Sharia Hotel performance 0.933, and all figures obtained above 0.80 and the reliable value of the three variables stated good fit.

\section{Hypotheses Testing}

Figure 1. Conceptual Frame work e1 $=0.879$

$$
\mathrm{P} 2=0.394
$$

$\mathbf{P} 3=0.378$

$$
P 1=0.305
$$

H1: Spiritual leadership has a positive and significant effect on Organisational Commitment 
Table. 3 Coefficient of Determination

\begin{tabular}{|l|r|r|r|r|}
\hline \multicolumn{1}{|c|}{$\begin{array}{c}\text { Model } \\
\text { Mummary }\end{array}$} & & & & \\
\hline Model & R & R Square & $\begin{array}{c}\text { Adjusted R } \\
\text { Square }\end{array}$ & $\begin{array}{c}\text { Std. Error of } \\
\text { the Estimate }\end{array}$ \\
\hline 1 & $.475^{\mathrm{a}}$ & .226 & .210 & 9.96626 \\
\hline $\begin{array}{l}\text { a. Predictors: } \\
\text { (Constant), } \\
\text { Spiritual } \\
\text { Leadership }\end{array}$ & & & & \\
\hline
\end{tabular}

The determination coefficient table shows the $\mathrm{R}$ square value of $22.6 \%$, which means that spiritual leadership influences the organisational commitment by $22.6 \%$, while the remaining $77.4 \%$ are unknown variables in this study.

Table. 4 Linear regression coefficients for Spiritual Leadership

\begin{tabular}{|c|c|c|c|c|c|c|}
\hline$\underset{a}{\text { Coefficients }}$ & & & & & & \\
\hline \multirow[t]{2}{*}{ Model } & $\begin{array}{l}\text { Unstandardized } \\
\text { Coefficients }\end{array}$ & $\begin{array}{c}\text { Standardized } \\
\text { Coefficients }\end{array}$ & $\mathrm{t}$ & \multirow[t]{2}{*}{ Sig. } & & \\
\hline & $\mathrm{B}$ & Std. Error & Beta & & & \\
\hline \multirow[b]{2}{*}{1} & (Constant) & 23.834 & 7.516 & & 3.171 & .003 \\
\hline & $\begin{array}{l}\text { Spiritual } \\
\text { Leadership }\end{array}$ & .394 & .105 & .475 & 3.745 & .000 \\
\hline $\begin{array}{l}\text { a. Dependent } \\
\text { Variable: } \\
\text { Commitment }\end{array}$ & & & & & & \\
\hline
\end{tabular}

From the results of the regression analysis in table 5, we could conclude that the Spiritual Leadership has a positive and significant effect on organisational commitment where the significance value of 0.000 is smaller than the alpha value of $5 \%$, which means that the more Spiritual Leadership a leader has, the higher his commitment towards the organisation.

H2: Organisational Commitment has a positive and significant effect on Sharia Hotels Performance

H3: Spiritual Leadership has a positive and significant effect on Sharia Hotels Performance

Table. 5 Coefficient of Determination

\begin{tabular}{|l|r|r|r|r|}
\hline \multicolumn{1}{|c|}{$\begin{array}{c}\text { Model } \\
\text { Summary }\end{array}$} & & & & \\
\hline Model & $\mathrm{R}$ & R Square & $\begin{array}{c}\text { Adjusted R } \\
\text { Square }\end{array}$ & $\begin{array}{c}\text { Std. Error of } \\
\text { the Estimate }\end{array}$ \\
\hline 1 & $.776^{\mathrm{a}}$ & .602 & .585 & 5.96663 \\
\hline $\begin{array}{l}\text { a. Predictors: } \\
\text { (Constant), } \\
\text { Commitment, } \\
\text { Spritual } \\
\text { Leadership }\end{array}$ & & & & \\
\hline
\end{tabular}

Based on table 6, the results showed that Sharia hotel performance is influenced by Spiritual Leadership and Organisational Commitment of $60.2 \%$ meaning that with spiritual leadership and good organisational commitment will influence sharia hotel performance because with 
these two variables can contribute more than $50 \%$ even though $40.8 \%$ is influenced by other variables which are also not mentioned in this study.

Table. 6 Linear regression coefficients for Commitment and Spiritual Leadership

\begin{tabular}{|c|c|c|c|c|c|c|}
\hline \multicolumn{7}{|l|}{ Coefficients $^{a}$} \\
\hline \multirow[t]{2}{*}{ Model } & $\begin{array}{c}\text { Unstandardized } \\
\text { Coefficients } \\
\end{array}$ & $\begin{array}{c}\text { Standardized } \\
\text { Coefficients }\end{array}$ & $\mathrm{t}$ & \multirow[t]{2}{*}{ Sig. } & & \\
\hline & $\mathrm{B}$ & Std. Error & Beta & & & \\
\hline \multirow{3}{*}{1} & (Constant) & 15.959 & 4.949 & & 3.225 & .002 \\
\hline & $\begin{array}{l}\text { Spritual } \\
\text { Leadership }\end{array}$ & .305 & .072 & .446 & 4.266 & .000 \\
\hline & Commitment & .378 & .086 & .458 & 4.376 & .000 \\
\hline $\begin{array}{l}\text { a. Dependent } \\
\text { Variable: } \\
\text { Sharia hotel } \\
\text { Performance }\end{array}$ & & & & & & \\
\hline
\end{tabular}

For hypothesis H2: Organisational Commitment has a positive and significant effect on Sharia Hotels, and this is evidenced by the significance value for the Organisational Commitment (Z) effect of 0.000 , which is smaller than the alpha value of $5 \%$.

And for hypothesis H3: Spiritual leadership has a positive and significant effect on Sharia Hotels. This finding is also evident with a significance value of 0.000 smaller when compared with an alpha of $5 \%$.

H4: The influence of Spiritual Leadership affects Sharia Hotels performance with Organisational Commitment as a mediating variable

The tools in this study use SPSS 21 tools, namely, path analysis. By employing the Sobel Test, we conclude that the influence of spiritual leadership on Sharia Hotels' performance with Organisational Commitment as a mediator with a $t$ value of 2.78 is greater than the $t$ table of 1.6787. And it can be proven that the organisational commitment variable mediates the relationship between spiritual leadership and Sharia hotel performance, where the analysis shows that the spiritual leader variable can directly influence sharia hotel performance and can also indirectly influence the mediating variable, where the direct effect is 0.305 . While the influence is not direct amounting to 0.1489 and the total influence of Spiritual Leadership on Sharia hotels' performance amounted to 0.454 .

\section{CONCLUSION}

As a country with the largest Muslim population in the world that is full of beautiful natural resources, Indonesia has a great opportunity to become a major destination for sharia travel. Three provinces are the main destinations for halal tourism in Indonesia, namely Aceh, West Sumatra and West Nusa Tenggara. For this reason, the kingdom and community of West Sumatra strongly support the implementation of halal tourism in West Sumatra. In this case, the Sharia lodging support industry, namely Sharia Hotels, must be provided with the concept of complete facilities for worship, a conducive environment, halal food and drinks, and a convenient place of worship.

In this case, the Sharia lodging support industry, namely Sharia Hotels, must be provided with the concept of complete facilities for worship, a conducive environment, halal food and drinks, and a convenient place of worship. Based on this research findings, organisational commitment as a mediator variable affects the relationship between Spiritual Leadership and Shariah 
Performance Hotels, where if a leader does a good job of not only saying but also doing what he says, it will impact the organisation's commitment which principled shariah hotel, thus impacting the performance of sharia hotels. To ensure that the shariah implementation of the hotel can is successful with the vision and mission set; human resources are needed to meet the goals of the organisation. Human resources are considered the most valuable asset in the organisation. Hence, the importance of organisational commitment is an organisational commitment as an individual orientation towards the organisation, which includes loyalty, identification, and involvement. Commitment has an important role, especially on one's performance when working, due to the existence of commitments that become a reference and encouragement that makes them more responsible for their obligations.

Thus, organisational commitment defines the orientation element between the individual and his organisation. And the relationship orientation results in individuals willing to give something and something that reflect the relationship for the achievement of organisational goals.

Individual commitment to the organisation is an important part of the process of individuals within the organisation itself. There is a very significant relationship between spiritual leadership and organisational performance that can increase commitment to the organisation. So, if the organisation makes the individual possess their inner satisfaction with the organisation, making the level of commitment to the organisation even higher.

Organisational commitment is one important factor for the success of an organisation. Without a strong organisational commitment in individuals, it will not be possible for an organisation to run effectively. Organisational commitment is also an important behavioural dimension that is to assess employee's tendency to remain as a member of the organisation, is the identification and involvement of someone who is relatively strong towards the organisation and the desire of members of the organisation to maintain their membership in the organisation and are willing to work hard for the achievement of organisational goals. Organisational commitment is achievable if the organisation follows the demand of its members, and vice versa what the organisation expects the number of member contributions. Employees will feel obliged to work in an organisation only if they trust their leaders. Trust is reciprocal, where if the leader trusts an employee, then he will also trust the leader. Leadership behaviour influences performance. The higher level of leadership behaviour will improve team performance in an organisation. The values of leadership behaviour are shown by loving behaviour, giving authority to subordinates, paying attention to organisational vision, and having a spirit of simplicity. The leader's performance is inseparable from the share of organisational performance. Therefore, the higher level of attention of leaders to members of humanity, delegation of authority, attention to the vision of the organisation, and the attitude of a leader's simplicity will have a positive effect on organisational performance, leadership development coupled with an increase in spirituality, in addition to increasing spiritual leadership behaviour that will have an impact directly on improving performance, can also provide a new perspective or paradigm of spirituality about the roles and tasks of leaders. Leaders and leadership are not just social symbols or positions, but more important are the roles and responsibilities in realizing the spiritual man. Effective human resources should lead to positive attitudes and behaviours in the workplace. On the other hand, ineffective human resource management can have a negative impact in the form of low commitment or high turnover and poor quality of the workforce. 


\section{References}

Jafari, J., \& Scott, N. (2014). Muslim World And Its Tourisms. Annals Of Tourism Research, 44(1), 1-19. Https://Doi.Org/10.1016/J.Annals.2013.08.011

Mohamed Battour, Mohd Nazari Ismail, Moustafa Battor \& Muhammad Awais(2014): Islamic Tourism: An Empirical Examination Of Travel Motivation And Satisfaction In Malaysia,Current Issues In Tourism, Doi: $10.1080 / 13683500.2014 .965665$.

Wtm. (2007). Global Trends Report.

Henderson, J. C. (2003). Managing Tourism And Islam In Peninsular Malaysia. Tourism Management, 24(4), 447456. Doi:10.1016/S0261-5177(02)00106-1.

Hamza, C. A., Stewart, S. L., \& Willoughby, T. (2012). Examining The Link Between Nonsuicidal Self-Injury And Suicidal Behavior: A Review Of The Literature And An Integrated Model. Clinical Psychology Review, 32(6), 482495. Https://Doi.Org/10.1016/J.Cpr.2012.05.003.

Battour, M., \& Ismail, M. N. (2016). Halal Tourism: Concepts, Practises, Challenges And Future. Tourism Management Perspectives, 19, 150-154. Https://Doi.Org/10.1016/J.Tmp.2015.12.008.

Henderson, J. C. (2009). Islamic Tourism Reviewed. Tourism Recreation Research, 34(2), 207-211. Https://Doi.Org/10.1080/02508281.2009.11081594.

Battour, M., Ismail, M. N., \& Battor, M. (2010). The Impact Of Destination Attributes On Muslim Tourist's Choice. International Journal Of Tourism Research, 13(6), 527-540. Doi:10.1002/Jtr.824

Faruki K. Al-Ahkām Al-Khamsah. (1966) : The Five Values. Islamic Studies. Mar;5(1):43-98

Yusof, M. F. M., \& Muhammad, M. Z. (2010). Introducing Shariah Compliant Hotels As A New Tourism Product: The Case Of Malaysia Malaysia ' S Tourism Industry Islamic Tourism In Malaysia. Entrepreneurship Vision 2020: Innovation, Development Sustainability, And Economic Growth 1145, 1142-1146.

Https://Doi.Org/10.1166/Asl.2015.6187

Samori, Z., \& Rahman, F. A. (2013). Establishing Shariah Compliant Hotels In Malaysia : Identifying Opportunities, Exploring Challenges. West East Journal Of Social Sciences, 2(2), 95-108.

Adinugraha, Hendri Hermawan., Sartika, Mila., Kadarningsih, Ana. (2018). Desa Wisata Halal: Konsep Dan Implementasinya Di Indonesia. Human Falah: Volume 5. No. 1 Januari - Juni 2018.

Firdausi, I., Marantika, S., Firdaus, Z.N., Sajidah, R., 2017. Lombok: Halal Tourism As A New Indonesia Tourism Strategy, In: March 13-15, 2017 Dubai (Uae). Presented At The March 13-15, 2017 Dubai (Uae), Heaig. Https://Doi.Org/10.15242/Heaig.H0317447..

World Halal Tourism Award. (2016). Abu Dhabi, Uni Emirat Arab. Https://Republika.Co.Id/Berita/DuniaIslam/Islam-Nusantara/16/12/08/Ohtyo2330-Ini-Para-Pemenang-World-Halal-Tourism-Awards-2016.

Dsn Mui . (2016). Fatwa Dewan Syari'ah Nasional Nomor 108/Dsn-Mui/X/2016 Tentang Pedoman Penyelenggaraan Pariwisata Berdasarkan Prinsip Syariah. Https://Tafsirq.Com/Fatwa/Dsn-Mui/PedomanPenyelenggaraan-Pariwisata Berdasarkan-Prinsip-Syariah .

Kahya, E. (2009). The Effects Of Job Performance On Effectiveness. International Journal Of Industrial Ergonomics, 39, 96-104..

Wadongo, B., Odhuno, E., Kambona, O., \& Othuon, L. (2010). Key Performance Indicators In The Kenyan Hospitality Industry: A Managerial Perspective. Benchmarking, 17(6), 858-875.

Https://Doi.Org/10.1108/14635771011089764.

Al-Jabari, B., \& Ghazzawi, I. (2019). Organizational Commitment: A Review Of The Conceptual And Empirical Literature And A Research Agenda. International Leadership Journal, 11, 78-119.

Allen, N. J., \& Meyer, J. P. (1990). The Measurement And Antecedents Of Affective, Continuance And Normative Commitment To The Organization. Journal Of Occupational Psychology, 63(1), 1-18. Http://Dx.Doi.Org/10.1111//.2044-8325.1990.Tb00506.X

Purcell J., And Hutchinson S. (2007). Front-Line Managers As Agents In The Hrm-Performance Causal Chain: Theory, Analysis And Evidence. Human Resource Management Journal, 17(1), 3-20..

Heskett J.L, Sasser W.E., And Schlesinger, L.A. (1994). Putting The Service Profit Chain To Work. Harvard Business Review, 72, 164-174. 
Larson J.A., And Sasser W.E. (2000). Building Trust Through Committed Employees. Marketing Management, 9(3), $40-46$.

Hellriegel, Slocum \& Woodman (2001). Organization Behavior (9th Ed.). Ohio: South-Western College Publishing. Lean, E. R. (2012). The Construct Development Of Spiritual Leadership. Phd Dissertation, University Of Arkansas, Sa.

Abbasi, A., Ur Rehman, K., \& Bibi, A. (2010). Islamic Management Model. African Journal Of Business Management, 4.

Fry, L.W., 2008. Spiritual Leadership: State-Of-The Art And Future Directions For Theory, Research, And Practice. In: J. Biberman And L. Tischler, Eds. Spirituality In Business. New York: Palgrave Macmillan, 106-124.

Jeon, K. S. (2011). The Relationship Of Perception Of Organization Performance And Spiritual Leadership, Workplace Spirituality, And Learning Organization Culture In The Korean Context, Phd Dissertation, The Graduate School, The Pennsylvania State University, Usa.

Benefiel, M., Fry, L. W., \& Giegle, D. (2014). Spirituality And Religion In The Workplace: History, Theory, And Research. Psychology Of Religion And Spirituality, 6(3), 175-187. Http://Dx.Doi.Org/10.1037/A0036597

Jerry, J. (2009). The Leadership Quarterly Special Issue On Spiritual Leadership. The Leadership Quarterly, 29(4), 491-492.

Lean, E. R. (2012). The Construct Development Of Spiritual Leadership. Phd Dissertation, University Of Arkansas, Sa.

Chun, C., \& Chin, Y, (2012). Spiritual Leadership, Follower Mediators, And Organizational Outcomes: Evidence From Three Industries Across Two Major Chinese Societies. Journal Of Applied Social Psychology, 42(4), 890-938.

Chen, C., \& Yang, C. (2012). The Impact Of Spiritual Leadership On Organizational Citizenship Behavior: A MultiSample Analysis. Journal Of Business Ethics, 105(1), Pp.107-114..

Choi, F. D., \& Mueller, S. (1992). What Is Coefficient Alpha? An Examination Of Theory And Application. J. Appl. Psychol. 78(2), 98-104.

Choi, F. D., \& Mueller, S. (1992). What Is Coefficient Alpha? An Examination Of Theory And Application. J. Appl. Psychol. 78(2), 98-104.

Fry, L.W., 2008. Spiritual Leadership: State-Of-The Art And Future Directions For Theory, Research, And Practice. In: J. Biberman And L. Tischler, Eds. Spirituality In Business. New York: Palgrave Macmillan, 106-124..

Naicker, N. (2008). Organizational Culture And Employee Commitment : A Case Study, (November), 1-121...

Wadongo, B., Odhuno, E., Kambona, O., \& Othuon, L. (2010). Key Performance Indicators In The Kenyan Hospitality Industry: A Managerial Perspective. Benchmarking, 17(6), 858-875.

Https://Doi.Org/10.1108/14635771011089764.

Hair, J.F. Jr, Black, W.C., Babin, B.J. And Anderson, R.E. (2010), Multivariate Data Analysis: A Global Perspective , 7th Ed., Pearson Education, Upper Saddle River, $\mathrm{Nj}$.

Sekaran, U. And Bougie, R. (2013) Research Methods For Business A Skill-Building Approach. 6th Edition, Wiley, New York. 